\title{
Kadın Gazetecilerde Mesleki Tükenmişlik ve Yaşam Doyumu
}

\author{
Burnout and Life Satisfaction in Female Journalists
}

\section{F. Sülen ŞAHİN KIRALP* Gülay ASIT**}

\begin{abstract}
Öz: Günümüzde çalışan kadın sayısı artmıştır. Ancak görülmektedir ki kadınlardan iş yaşamının gerekliliklerinin yanı sıra ev-aile yaşamının gerekliliklerini de yerine getirmesi beklenmektedir. Bu noktada devreye giren toplumsal cinsiyet kavramının kadına yüklediği roller, kadının tüm bunlarla başa çıkarken bazı psikolojik sıkıntılar yaşamasına da yol açmaktadır. Kişinin yaşam doyumunu yani yaşama karşı yönelimini etkileyebilen tükenmişlik sendromu da bunlardan biridir. Bu araştırmanın amacı kadın gazetecilerin mesleki tükenmişlik düzeyleri ile yaşam doyumu arasındaki ilişkinin incelenmesidir. Bu nedenle araştırma ilişkisel tarama türünde gerçekleştirilmiştir. Yapılan analizler sonucunda görülmüş̧ür ki çalışmaya katılan kadın gazetecilerin mesleki tükenmişlik düzeyleri (duygusal tükenme, duyarsızlaşma ve kişisel başarısızlık alt boyutları da dahil olmak üzere) yüksek ve yaşam doyum düzeyleri ise düşüktür. Tükenmişliğin yaşam doyumu üzerindeki anlamlı etkisinin tükenmişliğin hangi alt boyutundan kaynaklandığını bulmak için yapılan çoklu regresyon analizine ile duygusal tükenme alt boyutunun yaşam doyumu üzerinde etkisi olduğu ortaya konmuştur.
\end{abstract}

Anahtar sözcükler: Tükenmişlik, Yaşam Doyumu, Kadın Gazeteci, Gazetecilik

Abstract: Today, the number of working women has increased. However, it is seen that women as well as the necessity of a working life is expected to fulfill the requirements of the household-family life. The concept of gender imposes some roles on women. This may lead to some psychological troubles for women. Burnout syndrome is one of them, which can affect the life satisfaction of the person, that is, their direction towards life. The aim of this research was to examine the relationship between the occupational burnout levels and the life satisfaction of female journalists. For this reason, this research was conducted in the form of relational screening. As a result of the analysis that was made, it was found that female journalists have high occupational burnout levels and low life satisfaction levels. Multiple regression analysis was performed to determine which subscale of burnout has a significant effect upon life satisfaction. It was shown that the emotional exhaustion sub-dimension has an effect upon life satisfaction.

Keywords: Burnout, Life Satisfaction, Women Journalists, Journalism

\section{Giriş}

Bilindiği gibi kadının ücretli işgücüne katılması tarihsel olarak belli süreçlerden geçerek gerçekleşmiştir. Önceleri tarım işçiliği haricinde ev dışında çalışmayan kadın, daha sonraları terzilik, firıncılık gibi iş kollarında çalışmaya başlamış ve sanayi devrimi ile birlikte işgücünün belkemiği haline gelmiştir. Özellikle erkek işgücünün yeterli olmadığı zamanlarda (örneğin savaş

\footnotetext{
* Yrd. Doç. Dr. Lefke Avrupa Üniversitesi, Eğitim Fakültesi, RPD Bölümü, Lefke, fkiralp@eul.edu.tr,

${ }^{* *}$ PhD. Öğrencisi, Girne Amerikan Üniversitesi, Sosyal Bilimler Enstitüsü, İletişim Bölümü, Girne, gasit@gau.edu.tr
} 
dönemleri) ikame olarak görülmüştür. Ancak kadın işgücü erkek işgücü ile aynı beceri ve çıktıyı sağlayabilse de günümüzde ikincil durumda kalmaktan kurtulup kurtulamadığı hala tartışmalıdır.

Erkek egemen meslek grupları içerisinde kendisine yer bulmaya çalışan kadın, bir yandan rekabet ortamında tutunmaya çalışırken bir yandan da toplumsal cinsiyet kavramıyla mücadele etmek zorunda kalmıştır. Alanyazında toplumsal cinsiyet kavramı, "kadın ve erkek olarak toplumun bizi nasıl gördüğü, nasıl algıladığl, nasıl düşündüğ̈̈ ve nasıl davranmamızı beklediğ̈i” ile ilgili bir bir kavram olarak açıklanmaktadır (Akın 2007, 2). Örneğin kadının hizmet sektöründe önceleri genellikle öğretmenlik gibi mesai saatleri belli meslek gruplarında çalışması, bu mesleğin toplumsal cinsiyet rolleri açısından kadına uygun bir meslek olarak görülmesinden kaynaklanmaktadır. Ataerkil yapının kadına yüklediği ev işleri ve çocuk bakımı gibi roller onun çalışma yaşamından sonra ev halkının ihtiyaçlarını da yeterli şekilde ve zamanında karşılaması gerektiğini vurgulamaktadır. Bu nedenle erkek mesleği gibi görülen mimarlık, avukatlık, gazetecilik gibi mesleklerde kadınların yer alması zaman almıştır. Günümüzde pek çok iş alanı için bunun değiștiğini söylemek pek de mümkün görünmemektedir. Örneğin KKTC Devlet Planlama Örgütü Hanehalkı İş Gücü Anketi (2015) sonuçlarına göre istihdam edilenlerin \%35.9'u kadın, \%64.1'i ise erkektir.

Uzun yıllar bir erkek mesleği olarak kabul edilen gazetecilikte durum nasıldı ve kadınlar bu mesleğe ne zaman dahil oldu? Kıbrıs Türk basınında ilk gazetelerin Kıbrıs adası İngiliz yönetimi altındayken çıkarıldığı bilinmektedir. İlk Türk gazetesi Saded 11 Temmuz 1889'da yayınlanmıştır (Ünlü n.d. akt. İrvan 2006). İrvan (2006) çalışmasında 1889-2005 yılları arasında 80 gazete adına rastlandığını belirtmektedir. Bu gazetelerin sahiplerine bakıldığında sahibinin kim olduğu belirtilmemiş birkaç gazete dışındakilerin içinde sadece bir tanesinin sahibinin bir kadın gazeteci olduğu görülmektedir. Bu kişi 1943-1946 yılları arasında da Söz gazetesinin sahibi olan Bedia Okan'dır. Kıbrıs basınında ilk Türk kadın gazeteci olarak anılan Okan, gazeteciliğe Söz gazetesinde, gazetenin sahibi olan babası Remzi Okan'ın yanında başlamıştır. Çok uzun yıllar Bedia Okan ve kız kardeşleri dışında (kardeşlerinin muhabirlik değil yayında görev aldıkları belirtilmektedir) Kıbrıs Türk basın hayatında kadın gazeteciye rastlanmamıştır. Türkiye'de ise 1900'lü yılların başında gazetecilik yapan Selma Rıza ilk kadın gazeteci olarak çalışmıştır (Karaman 2006).

Genel olarak bakıldığında birçok ülkedeki medya sektöründe kadın çalışanların sayısının 1960'lardan sonra arttı̆̆ belirtilmektedir (Aybay 2006). Bunda Feminist hareketin etkisi olduğu düşünülebilir. Alan yazındaki çalışmalara bakıldığında (Delano 2003; Aybay 2006) kadın gazetecilerin yıllar içindeki sayısının arttığı söylenebilir. Kuzey Kıbrıs'taki örneklem için bakıldığında İrvan'ın (2006) yaptığı araştırmaya katılan kadınların oranı \%37'iken, Şahin'in 2013 yılında yaptığ çalışmaya katılan kadın gazetecilerin oranının \%62 olduğu görülmüştür.

Çalışma hayatında kadınların yaşadığı sorunların genel olarak bilgi ve becerilerinden ziyade cinsiyetleriyle ilgili olduğu düşünülmektedir. Cinsiyetin içinden çıkan cinsiyetçilik kavramı "temelde bir cinsiyetin diğerinden üstün olduğunu savunur ve bu düşüncenin sürdürülmesine yol açacak söylemlerde bulunur" (Avdullahu 2015, 15). Yani kadından hem mesleği için hem de aile hayatı için uğraş vermesi beklenirken erkek çalışanla aynı şartlara sahip olmadığ söylenebilir. Kadının bilgi ve beceri olarak nitelikli bir çalışan olsa bile ikincil seçenek durumunda kalması gazetecilikle birlikte hemen her iş alanında sıklıkla görülmektedir. $\mathrm{Bu}$ da kadının hayatındaki önemli stresörlerden biri olarak kabul edilebilir. İş yaşamında sürekli hale gelen stres, alan yazındaki çalışmaların da ortaya koyduğu gibi (Yılmaz \& Ekici 2003; Yumuk, Günay \& Demiralay 2016) tükenmişlik kavramını akla getirmektedir. 
Günlük yaşamın getirdiği stresler, iş yaşamı stresleri ve modern dünyanın yarattığı stres kaynakları günümüz insanının en temel sıkıntılarından biri haline gelmiştir. Stresin bilinen pek çok olumsuz etkisi vardır. Bunlardan biri de 1970'li y1llarda ortaya atılmış olsa bile güncelliğini hiç yitirmemiş olan “tükenmişlik"tir. Bu kavramı ilk ortaya aran kişi olan Freudenberger (1974) tükenmişliği şöyle tanımlamaktadır; tükenmişlik başarısızlık, yıpranma, enerji ve güç kaybı veya insanın iç kaynakları üzerinde karşılanamayan istekler sonucunda ortaya çıkan bir tükenme durumudur. Alan yazında Freudenberger'den sonra en fazla kabul gören tanımın sahibi olan Maslach ve Jackson (1981) ise tükenmişliği şöyle tanımlarlar: İnsanda ortaya çıkan fiziksel bitkinlik, uzun süren yorgunluk, çaresizlik ve umutsuzluk duyguları, yaptığı işe, hayata ve diğer insanlara karşı olumsuz tutumları kapsayan fiziksel ve zihinsel boyutlu bir sendromdur.

Alan yazındaki çalışmalarda (Şahin 2013; Yıldırım 2016) görülebileceği gibi tükenmişlik, özellikle insanlarla yoğun şekilde çalışılan meslek mensuplarının iş yerinde yaşadıkları yoğun stres sonucunda oluşur. Burada fiziksel yorgunluğa duygusal yorgunluğun da eklenmesi söz konusudur. Üç boyutta incelenebilen tükenmişlik; duygusal açıdan tükenme, hizmet sunduğu insanlara karşı duyarsızlaşma ve artan kişisel başarısızlıkla sonuçlanan bir sendromdur.

Çalışan bireyleri tükenmişlik durumuna götüren pek çok etken söz konusudur. Fazla iş talebi, işle ilgili yüksek beklenti, işin çalışma şekli ve koşulları, yaptığı işte değer görmediğini düşünme, zorlu çalışma saatleri tükenmişlik olgusunu kuvvetlendirir. Tüm bunların yanı sıra aşırı sorumluluk alma durumu, yoğun ve baskılı iş ortamları, hafta sonu tatili kavramlarının net olmaması gibi durumlar tükenmişliğe yol açan etkenler arasında sayılabilir (Şahin 2013). Bir kurumda tükenmişliğin sonucu olarak sıklıkla ifade edilen iki temel konu vardır; birincisi kuruma bağlılı̆̆ın azalması, ikincisi işten ayrılma niyetinin artması (Jung \& Kim 2012). Bu da sadece birey için değil çalıştığı kurum için de bir sorun kaynağı olacaktır. Çünkü tükenmişlik kişide işe gitmek istememenin yanı sıra işi gereken özenle yapmama, performansta azalma gibi pek çok olumsuz tutumu da beraberinde getirecektir.

Yaptığ 1 işten tatmin sağlamak bireyin yaşam doyumunda ve üretkenliğinde önemli bir yere sahiptir. Yaşam doyumu bireylerin kendi seçtikleri ölçütlere göre yaşam kalitelerinin genel değerlendirmesi olarak tanımlanır (Diener et al. 1985). Yaşamda çeşitli konularda karşılaşılan engellemeler, yetersizlik hissi, maddi sorunlar, iş yerindeki sorunlar, sağlık sorunları gibi etkenlerin yaşam doyumunu olumsuz etkiledikleri bilinmektedir. Bireyin yaşam doyumuna olumlu ya da olumsuz katkısı olan etkenleri ortaya koyarak daha fazla doyum, daha az tükenme yaşamasinı (Ünal, Karlıdağ \& Yoloğlu 2001) kolaylaştırmak yönünde çalışmalar yapmak tüm iş kolları için gereklidir.

Özetlenen bu görüşlerden hareketle araştırmada kadın gazetecilerin mesleki tükenmişlik düzeyleri ile yaşam doyumları arasındaki ilişki ortaya konmaya çalışılmıştır. Ayrıca araştırma sonucunda mesleki tükenmişlik ile yaşam doyumu arasındaki ilişkinin yönü ve düzeyinin ortaya konması amaçlanmıştır. Bu genel amaç doğrultusundan aşağıdaki alt problemlere yanıt aranmıştır;

1. Kadın gazetecilerde mesleki tükenmişlik düzeyi ile yaşam doyumu arasında ilişki var midir?

2. Kadın gazetecilerin mesleki tükenmişlik düzeyi alt boyutları yaşam doyumunu anlamlı düzeyde yordamakta mıdır?

\section{Yöntem}

\section{Araştırmanın Modeli}

$\mathrm{Bu}$ araştırma kapsamında kadın gazetecilerin mesleki tükenmişlik ve yaşam doyum düzeyleri 
arasındaki ilişki incelenmiştir. Bu nedenle betimsel bir yaklaşımla yürütülen çalışma ilişkisel tarama modelinde gerçekleştirilmiştir. Heppner, Wampold ve Kivlighan (2013)'e göre betimsel desenler belirli bir olgunun özelliklerini kanıtlamada ve varlığını tarif etmede önemli rol oynar. Tarama desenleri ise söz konusu değişkenlerin varlığını ve sıklığını tarif etme konusunda araştırmacılara olanak sağlar. Basit ilişkisel desen iki değişken arasındaki ilişkiyi araştırır ve daha sonra bu ilişkileri tanımlamak için korelasyon analizi kullanır (Heppner, Wampold \& Kivlighan 2013; Metin 2015). Buna göre ilişkisel araştırma yöntemi araştırmacılara değişkenler arasındaki ilişkileri açıklama ve sonuçları tahmin etme fırsatı sunar (Metin 2015).

\section{Çalışma Grubu}

Araştırmanın çalışma grubunu Kuzey Kıbrıs'ta sarı basın kartı sahibi kadın gazeteciler oluşturmaktadır. Veri toplama sürecinde soruları gönüllü olarak yanıtlamayı kabul eden 49 kadın gazeteciye ulaşılmıştır. Gazetecilerin \%67.3'ü evli, \%32.7 ise bekar olduklarını belirtmişlerdir. Ayrıca \%63.3'ü çocuğu olduğunu belirtmiştir. Öğrenim düzeylerine göre bakıldığında ise kadın gazetecilerin \%22,4'nün lise, \%61,2'sinin üniversite ve \%16,4'nün ise yüksek lisans düzeyinde oldukları görülmüştür. Ayrıca çalıştıkları pozisyonlara bakıldığında görülmüştür ki \%16.3’ü yönetici, \%83. 7'si ise çalışan pozisyonundadır.

\section{Veri Toplama Araçları}

\section{Maslach Tükenmişilik Ölçeği}

Araştırmaya katılan kadın gazetecilerin mesleki tükenmişliklerini ölçmek için Maslach ve Jackson (1981) tarafından geliştirilen Maslach Tükenmişilik Ölçeği kullanılmıştır. Ölçeğin Duygusal Tükenme (DT), Duyarsızlaşma (D), ve Kişisel Başarı (KB) olmak üzere 3 alt boyutu vardır. Her boyut için ayrı puan hesaplanabilmektedir. DT ve D boyutları olumsuz KB boyutu olumlu yanıtlar içerir. Ölçeğin orijinalinde Cronbach Alfa güvenirlik katsayıları DT için 0.86, D için 0.72 ve KB için 0.74 olarak hesaplanmıştır. Türkçeye uyarlaması Ergin (1992) tarafından yapılan ölçeğin Cronbach Alfa güvenirlik katsayıları DT için 0.83, D için 0.65 ve KB için 0.72 olarak hesaplanmıştır. Ölçek orijinalinden farklı olarak 5'li likert ölçeği formundadır. Şahin'in (2013) Kuzey Kıbrıs örneklem ile yaptığı çalışmada Cronbach Alfa güvenirlik katsayılarını DT için 0.82 , D için 0.68 ve KB için 0.71 olarak hesaplamıştır. Literatür taraması sonucunda bu ölçeğin tükenmişlik düzeyini saptamada en fazla tercih edilen ölçek olduğu görüldüğünden ve Türk kültürü için de dahil olmak üzere pek çok çalışmada tekrarlanan geçerlik ve güvenirlik çalışmalarının doyurucu sonuç vermiş olması bu ölçeğin tercih edilmesinde etken olmuştur.

\section{Yaşam Doyumu Ölçeği}

Ölçek Diener ve arkadaşları (1985) tarafından geliştirilmiştir. Ölçek bireylerin yaşam doyum düzeylerini belirlemek amacındadır. Ölçekte 5 soru yer almaktadır ve 7'li likert (hiç uygun değil ile tamamıyla uygun arasında değişen) türündedir. Diener ve arkadaşları (1985) ölçeğin testtekrar test güvenirlik katsayısını 0.82 olarak hesaplamışlardır. Madde analizi sonucunda madde test korelasyonu yeterli bulunmuştur (.67 ile 0.75 arasında). Türkçe uyarlaması Köker (1991) tarafından yapılan ölçeğin geçerlik çalışmasında madde analizi sonucu ölçeğin madde test korelasyonu yeterli bulunmuştur (0.71 ile 0.80) arasında. Ayrıca ölçeğin test tekrar test güvenirlik katsayısı .85 olarak saptanmıştır.

\section{Verilerin Analizi}

$\mathrm{Bu}$ araştırmada kadın gazetecilerin mesleki tükenmişlik düzeyleri ile yaşam doyumları arasındaki ilişkiye bakılmıştır. Normallik varsayımı Shapiro-Wilks ile test edilmiş̧ir. Elde edilen 
puanların basıklık ve çarpıklık değerlerinin +1.5 ile -1.5 arasında yer aldığı görüldüğünden veri analizinde parametrik ölçümlerden yararlanılmıştır (George \& Mallery 2010; Tabachnick \& Fidell 2013). Tükenmişlik düzeyi ve yaşam doyumu arasındaki ilişkiyi saptamak için korelasyon analizi kullanılmıştır. Tükenmişlik düzeyinin yaşam doyumunu yordayıp yordamadığını anlamak için ise regresyon analizi yönteminden faydalanılmıştır. Yaşam doyumunu en iyi yordayan tükenmişlik boyutunu belirlemek için çoklu regresyon analizi uygulanmıştır. Çoklu regresyon analizi ile yordayıcı değişkenin nasıl tek bir bağımlı değişkenle ilişki olduğu tanımlanabilmektedir (Heppner, Wampold \& Kivlighan 2013). Çözümlemelerde SPSS 20,0 programından yararlanılmıştır.

\section{Bulgular}

Kadın gazetecilerin tükenmişlik düzeyleri ve yaşam doyumları arasındaki ilişkiyi incelemek amacıyla yapılan bu çalışmanın veri analizinin ilk aşamasında katılımcıların tükenmişlik düzeyinin alt boyutlarına ilişkin puan ortalamaları ve yaşam doyum düzeyi puan ortalamaları belirlenmiş̧ir. Elde edilen ortalamalarından yaşam doyumu ve tükenmişlik düzeyi genel durumu ortaya konmuştur. Elde edilen verilerin ortalamaları ve standart sapma değerleri tablo 1'de verilmiştir. Daha sonra iki değişken arasındaki korelasyon hesaplanmıştır.

Tablo 1. Yaşam Doyumu ve Tükenmişlik Ölçeklerinden Alınan Puan Ortalamaları ve Standart Sapmaları

\begin{tabular}{|c|c|c|c|c|}
\hline \multirow{2}{*}{\multicolumn{2}{|c|}{ Yaşam Doyumu }} & \multicolumn{3}{|c|}{ Tükenmişlik Alt Boyutları } \\
\hline & & DT & $\mathrm{D}$ & $\mathrm{KB}$ \\
\hline Ortalama $(\overline{\mathrm{X}})$ & 15,1224 & 23,1020 & 10,0204 & 27,8776 \\
\hline Std. Sapma (SD) & 5,84035 & 6,59307 & 4,09008 & 6,29693 \\
\hline
\end{tabular}

Araştırmada yer alan kadın gazetecilerin yaşam doyumu ölçeğinden aldıkları puan ortalamalarına bakılırsa yaşam doyumu düzeylerinin düşük olduğu görülebilir $(\bar{X}=15,12)$. Kadın gazetecilerin ölçekten aldıkları minimum değer 6 ve maksimum değer ise 32 olarak saptanmıştır. Tükenmişlik ölçeği alt boyutlarına göre ise duygusal tükenme (DT), duyarsızlaşma (D) ve kişisel başarı (KB) alt boyutlarında aldıkları puan ortalamalarına göre yüksek düzeyde duygusal tükenme ve duyarsızlaşma yaşadıkları $\left(\bar{X}_{\mathrm{DT}}=23,10 ; \bar{X}_{\mathrm{D}}=10,02\right)$ ve kişisel başarı hissini ise düşük düzeyde yaşadıkları $\left(\overline{\mathrm{X}}_{\mathrm{KB}}=27,88\right)$ görülmektedir. Alt boyutlardan alınan minimum ve maksimum değerler ise şöyledir; DT minimum 10 maksimum 39; D minimum 5 maksimum 24 ve KB minimum 11 maksimum 40.

Kadın gazetecilerin tükenmişlik ölçeğinin alt boyutlarından ve yaşam doyum ölçeğinden aldıkları puanlara göre yüzdelik dağılımları tablo 2 de verilmiştir.

Tablo 2. Tükenmişlik Ölçeği Alt Boyut Puanlarına ve Yaşam Doyum Ölçeği Puanlarına Göre Yüzdelik Dağılımlar

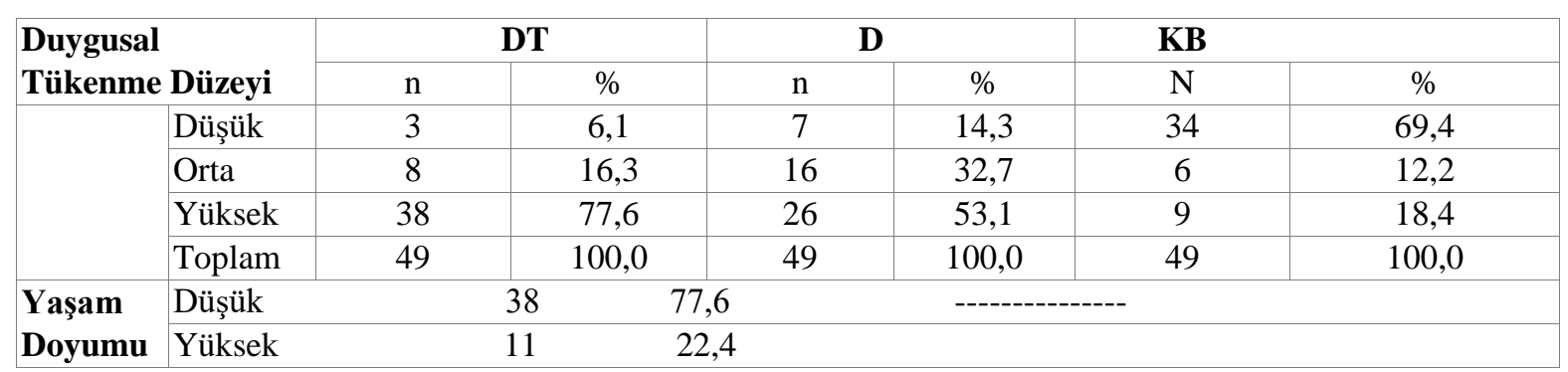


Tablodan da görüleceği gibi kadın gazetecilerin \%77,6's1 yüksek düzeyde duygusal tükenme, \%53.1'i yüksek düzeyde duyarsızlaşma yaşarken \%69,4'ünün kişisel başarı hissi düşüktür. Yaşam doyumu puanlarına baktığımız zaman kadın gazetecilerin \%77,6'sının yaşam doyum düzeylerinin düşük olduğu görülmektedir.

Bir sonraki adım, araştırmanın bağımlı değişkeni olan yaşam doyumu ve bağımsız değişkeni olan mesleki tükenmişlik arasından herhangi bir ilişki olup olmadığını saptamak olmuştur.

Tablo 3. Yaşam Doyumu Yordanmasına İlişkin Basit Doğrusal Regresyon Analizi Sonucu

\begin{tabular}{|l|l|l|l|l|l|l|l|}
\hline Model 1 & \multicolumn{7}{|c|}{ Tahmin Edilen Değişken: Yaşam Doyumu } \\
\hline Değişkenler & B & ShB & B & t & p & İkili r & Kısmi r \\
\hline Sabit &,- 59 & 4,36 & &,- 14 &, 89 & & \\
Tükenmişlik &, 26 &, 07 &, 47 & 3,66 &, 00 &, 47 &, 47 \\
\hline
\end{tabular}

Yukarıdaki tabloda da görüldüğü gibi gazetecilerin tükenmişlik düzeylerinin yaşam doyumu üzerinde $(\mathrm{F}(1,48)=13,37, \mathrm{p}=.000)$ anlamlı bir etkisi vardır. Bu modele göre gazetecilerin tükenmişlik düzeyleri yaşam doyumlarındaki varyansın $\% 22,18$ 'ini açıklamaktadır $(\mathrm{R}=0.47, \mathrm{R} 2$ $=0,22$ ). Yapılan analiz sonucunda tükenmişliğin yaşam doyumunu etkilediği görülse de tükenmişliğin hangi boyutunun yaşam doyumunu tam olarak açıkladığını anlamak için çoklu regresyon analizi yapılmıştır.

Tablo 4. Yaşam Doyumu Yordanmasına İlişkin Çoklu Regresyon Analizi

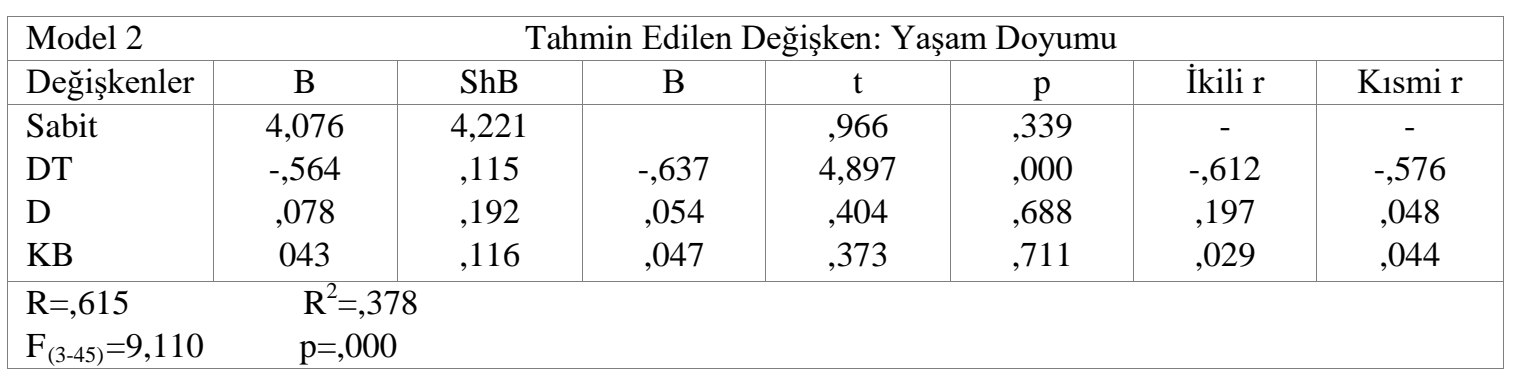

Tükenmişlik boyutlarının yaşam doyumunu yordama gücü standart çoklu regresyon analizi ile değerlendirilmiştir. Bağımlı değişkendeki değişimin \%38'ini DT, D ve KB ile açıklanabilir. Tablo 3'de de görüldüğü gibi $f$ değeri modelimizin bütün olarak anlamlı olduğunu göstermekte$\operatorname{dir}(\mathrm{p}=.000)$. Ancak parametrelere ait $\mathrm{t}$ istatistik değerlerinden modele dahil edilen her bir değişkene baktığımızda sadece DT alt boyutunun anlamlı olduğu görülmektedir. Tabloda görülebileceği gibi sabit terim 4,076 olarak bulunmuştur. Buna göre D ve KB alt boyutunun yaşam doyumu üzerinde etkisi olmasa da DT alt boyutunun etkisi olduğu görülmektedir.

\section{Tartışma, Sonuç ve Öneriler}

İnsanın yıllar içinde giderek artan ve değişen ihtiyaçlarını karşılamak için verdiği mücadele giderek zorlaşmaktadır. Gündelik yaşamın stresörleri olarak adlandırabileceğimiz bu zorluklar özellikle kadın açısından toplumsal cinsiyet rollerinin de baskısı ile bir kat daha artmaktadır. Bu nedenle bu araştırmada kadın gazetecilerin yaşam doyumu ve mesleki tükenmişlikleri arasındaki ilişki ele alınmıştır.

Araştırmadan elde edilen sonuçlara bakıldığında kadın gazetecilerin yaşam doyum düzeylerinin düşük olduğu ve yüksek düzeyde mesleki tükenme yaşadıkları belirlenmiştir. 
Yoğun stres faktörlerinin yanı sıra özellikle iş ve iş yaşamı ile ilgili olumsuz durumların bireylerin yaşam doyum düzeylerini olumsuz etkiliyor olduğu söylenebilir. Yaşam doyumu, öznel iyi oluşun olumlu etki, olumsuz etki ve yaşam doyumu olarak ifade edilen üç bileşeninden biridir. İlk iki bileşen duygusal yönü sonuncusu ise daha çok bilişsel yönü ifade eder (Diener et al. 1985; Pavot et al. 1991). Buna göre yaşam doyumu bir bireyin yaşamının tüm yönleri ile ilgilidir demek daha doğrudur. Her birey kendi yaşantıları, koşulları, ihtiyaçları ve kriterleri doğrultusunda yaşamını değerlendirir. Bu nedenle daha çok öznel bir yönü temsil eder. Bireysel farklı1ıkların önemli rol oynadığ referans çerçevesinden bir anlam yüklediği yaşantı temelli bir durumdur. Bu nedenle bireylerin yaşam doyumlarını etkileyecek farklı nedenler olduğu düşünülebilir. $\mathrm{Bu}$ araştırmada, iş ve iş yaşamından kaynaklanan yoğun strese bağlı tükenmişlik duygusunun yaşam doyumu üzerindeki etkisi incelenmiştir. Yapılan analizler sonucunda yaşam doyumu düzeyi ile mesleki tükenme arasında etkileşim olduğu söylenebilir. Araştırmaya katılan kadın gazetecilerin \%65'inin bu mesleği isteyerek seçtiğini belirtmiş olmasına karşın şu anda yüksek düzeyde tükenmişlik duygusu yaşaması iş performansı ve bireylerin yaşam kalitesi açısından göz önünde bulundurulmas1 gereken bir durumdur.

Mesleki tükenmişlik alt boyutları açısından bakıldığında araştırmaya katılanların çoğunluğunun yüksek düzeyde DT yaşadıkları görülmüştür. Tükenmişlik sendromu yaşayan bireylerin durumlarını anlatırken ifade ettikleri belirtiler daha çok DT boyutu ile ilgilidir (Polatçı, Ardıç \& Türkan 2014). Tükenmişliğin başlangıcı olarak kabul edilebilecek olan DT boyutunda bireyin temel sorunu doğrudan kendisi ile ilgilidir. Bireyde daha çok yorgunluk, halsizlik, enerji eksikliği, iş yapma gücü bulamama ile kendini belli eder. Stres faktörü bu boyutta belirgindir. DT için en net söylenebilecek neden fazla çalışma, uygun olmayan iş koşulları ve iş yerinde yaşanan çatışmalardır. Bunlar da gazetecilik mesleğinde sık görülen durumlardır. Ev ve aile yaşamının da etkileri birleştiğinde bu boyuttaki tükenme hissinin artmış olacağı söylenebilir. Özellikle amaca ulaşamamak, sosyal destek eksikliği de tükenmişliğin nedenleri arasında sayılabilir. İş ve ev yaşamı arasındaki görevlere yetişmeye çalışırken kendisi sosyal destek görmeyen kadının, tükenme, bitme duyguları yaşayabileceği söylenebilir. Anne, eş, arkadaş ve çalışan rollerinin hepsini mükemmel bir şekilde yerine getirmeye çalışmak, bunu yapamadığını, yetersiz olduğunu görmek veya bu yönde hissetmesine neden olmak kadında duygusal sıkıntılara yol açabilir.

Duyarsızlaşma boyutu tükenmişliğin kişilerarası iletişim boyutunu temsil etmektedir (Maslach \& Goldberg 1998). Hizmet verdiği kişilere karşı soğuk, mesafeli ve ilgisiz tavırlarla kendini belli eder. $\mathrm{Bu}$ tavırlarla birey bilinçli şekilde kendini diğerlerinden uzak tutar ve durumun yarattı̆̆ 1 stres ve gerginlikten uzak kalır. Maslach ve Goldberg (1998) bunu insanlar arasında kullanılan bir duygusal tampon olarak ifade ederler. Duyarsızlaşma boyutunu kadın gazetecilerin mesleğin yarattığı genel zorluklar karşısında bir savunma mekanizması olarak kullanmayı tercih ettikleri düşünülebilir. Çünkü uzun çalışma ve zor çalışma koşulları, haber yetiştirme için zaman ile yarışma, duygusal yıkıma neden olacak haberler yapmak bu mesleğin stresörleri olarak kabul edilebilir. Bu da kadın gazetecilerin duyarsızlaşma boyutundaki tükenme nedenlerinin bir ifadesi olabilir.

KB hissi genellikle yüksek düzeyde DT ve D’nin bir sonucu olarak kabul edilir. Kadın gazetecilerin de kişisel başarısızlık hissi yaşıyor olmaları bu durumda DT ve D sonucu olarak algılanabilir. Örneğin araştırmada yer alan kadın gazetecilerin sadece $\% 16,3$ 'ünün yönetici pozisyonunda çalıştığı görülmüştür. İkinci planda kalma hissi, yaptığı işin karşılığını alamama düşüncesi, mesleğin diğer zorlukları ile birleşerek $\mathrm{KB}$ hissini artırarak yaşam doyumunu 
olumsuz etkiliyor olabilir. Bu noktada kadınların yaptıkları işi, mesleki yeterliliklerini sorgulayarak kendi başarı hislerini olumsuz olarak değerlendirdikleri düşünülebilir. Tüm bunlara bakarak kadın gazetecilerin yorgunluk ve bıkkınlı hissinin yanı sıra temasta oldukları kişiler ile arasına mesafe koyduğu ve kişisel başarı hissinin de düşük olduğu ifade edilebilir.

Literatürde yer alan kadın ve erkek çalışanları karşılaştıran araştırmalara bakıldığı zaman kadın ve erkek arasında fark olmadığını belirten araştırmalar (Doğan, Demir \& Türkmen 2016) olduğu gibi fark olduğunu ortaya koyan araştırmalar da mevcuttur. Polatçı, Ardıç ve Türkan (2004) yaptıkları çalışmada kadınların daha fazla DT yaşadıklarını ortaya koymuşlardır. Barut ve Kalkan (2002) ise duyarsızlaşma ve KB boyutlarında kadınların erkeklere göre tükenmişlik düzeylerinin daha yüksek olduğunu bulmuşlardır. Avşaroğlu, Deniz ve Kahraman (2005) kadınların kişisel başarısızlık hissini daha yoğun yaşadıklarını ortaya koymuşlardır. Reinardy (2009) ise tüm alt boyutlarda kadın gazetecilerin tükenme yaşadıklarını belirtmiştir. Kısaca cinsiyete yönelik araştırmalara bakıldığında farklı sonuçlar olduğu görülmektedir.

Yaşam doyumu ve tükenmişlik arasındaki ilişkiye bakıldığında ikisi arasında negatif yönde bir korelasyon olduğu görülmüştür. Literatüre bakıldığında Avşaroğlu, Deniz ve Kahraman (2005), Gürel ve Gürel (2015), Çelik (2016) ve Uslan'ın (2016) da yaşam doyumu ve duygusal tükenme boyutu arasında negatif yönlü anlamlı değişiklik saptadıkları görülmektedir. Bu sonuçlar eldeki araştırma verisini destekler niteliktedir. Yapılan analizlere göre yaşam doyumundaki düşüklük DT boyutu ile ilgilidir. Bir başka ifadeyle DT düzeyinin yüksek oluşu yaşam doyum düzeyini düşürmektedir. Buna göre DT tükenme yaşayan kişi, sabah uyandığında kendini işe gidecek enerjiden yoksun hissedecektir. Ayrıca söz konusu kişi yorgun bıkkın, bunalmış hissetmenin yanı sıra bazı fizyolojik sıkıntılar da (uykusuzluk, hazımsızlık vb.) yaşayabilir. Bu durumdaki kişiler hizmet verdiği, beraber çalıştığ 1 veya hizmet aldığı kişilere ve onların ihtiyaçlarına cevap vermek istemeyerek genel bir yılgınlık duygusu içinde olabilirler. Bu noktada mesleğin kendine has stres kaynakları da bunlara dahil olunca tükenmişlik düzeyi yükselir. Örneğin Hastalık Kontrol ve Önleme Merkezleri (CDC) 2005 y1lında gazeteciliği dünyadaki en stresli meslekler arasında yedinci siraya koymuştur (CDC 2005). Avdullahu (2015) ise Kosovalı kadın gazeteciler ile yaptığı çalışmada en büyük zorluğun mesai saatlerinin uzunluğu ve belirsizliği olduğunu ortaya koymuştur. Kılıç ise (2013) kadından önce anne ve eş olarak toplumsal rolleri üstlenmesinin beklenmekte olduğunu ve mesleki başarı ve kariyerin ikinci planda kaldığını belirtmektedir. Kısaca ev yaşamının ve toplumun kadından beklentileri kadınlar için işi daha da stresli hale getirmektedir. Zaman zaman da kadın iş-aile-toplum çatışması ile baş etmek zorunda kalmaktadır. Alpsoy'un (2016) araştırmasına katılan kadın gazeteciler, meslekleri ile ev işlerini bir arada yürütme konusunda özveride bulunmak durumunda olduklarını ve mesleğe özgü sorunların yanı sıra kadın olmaktan kaynaklı problemlerle de karşılaştıklarını (ikinci planda tutulmak, taciz gibi) belirtmişlerdir. Görüldüğü gibi kadın sadece mesleğin stresörleri ile değil aynı zamanda görünmez bir el gibi kendini hissettiren cinsiyet ayrımı, aile konuları, toplumsal beklentiler (çocuk ile ve ev ile ilgilenmek) yüzünden de daha fazla etkilenmektedir. KAYAD (2010) Kuzey Kıbrıs'ta yaptığı araştırmada, araştırmaya katılan kadınların \%51'ine göre 'toplumda kadın ve erkeğin nasıl davranması gerektiği bellidir ve buna uyulması gerekir'. Ayrıca araştırmaya katılan kadınların \%88'i 'kadının her şeyden önce iyi bir anne ve ev hanımı olması gerektiğine' ve \%80'i ise kadınların kızlarını 'hanım' ve oğullarını 'erkek' gibi yetiştirmeleri gerektiği yönünde görüş bildirdiklerini ortaya koymuştur. Çok doğrudan etkileri ispat edilmese de toplumun beklentileri ile paralel olan bu gibi algıların kadın üzerinde baskı yaptığı söylenebilir. Tüm bu nedenlerden dolayı kadınların yüksek düzeyde tükenme ve buna eşlik eden yaşam doyumunda bir azalma duygusu yaşadıklarından söz edilebilir. Hatta bunun yaşam yönelimini olumsuz etkilediği söylenebilir çünkü kendini tüketen 
mesleğe rağmen yeni bir işe geçmek için istek veya çabası olmadığ yönünde yorumlanabilir.

Eldeki verilere dayanarak bu araştırmanın daha geniş bir örneklemle, nitel araştırma yöntemlerinin de dahil edilerek çalışılmasının yeni bilgilere ışık tutacağ düşünülmektedir. Daha sonra yapılacak çalışmalarda iş doyumunun da araştırmaya dahil edilmesinin faydalı olacağı düşünülmektedir. Mesleki tükenmişlik yaşayan bireylere yönelik iş yerlerinde stresle başa çıkma, iş yerinde stres gibi konularda eğitimler ve danışma hizmetleri sağlayarak kadın gazetecilerin stres kaynakları ile daha etkili başa çıkması sağlanabilir.

Kadın gazetecilerin iş yerinde yaşam doyumunu artıracak ve mesleki tükenme duygusunu azaltacak çeşitli düzenlemelerin yapılması için iş yerlerine yönelik araştırmaların geliştirilmesi önerilebilir. Bu sayede çalışanların işlerinde ve yaşamlarında daha istekli ve doyurucu şekilde faaliyetlerde bulunmaların katkı sağlayacaktır.

\section{KAYNAKÇA}

Akın A. (2007). “Toplumsal Cinsiyet Ayrımc1lığı ve Sağlık”. Toplum Hekimliği Bülteni 26/2 (2007) 1-9.

Alpsoy İ. (2016). Erzurum Yerel ve Yaygin Basın Kuruluşlarında Çalışan Kadın Gazeteciler Üzerine Bir Alan Araştırması. Yayımlanmamış Yüksek Lisans Tezi. Atatürk Üniversitesi, Sosyal Bilimler Enstitüsü, Erzurum 2016.

Avdullahu A. (2015). Medyada Kadın İşgücü ve Cinsiyetçilik: Kosova'daki Kadın Gazeteciler Örneği. Yayımlanmamış Yüksek Lisans Tezi. Ege Üniversitesi, Sosyal Bilimler Enstitüsü, İzmir 2015.

Avşaroğlu S., Deniz M. E. \& Kahraman A. (2005). "Teknik Öğretmenlerde Yaşam Doyumu ve Mesleki Tükenmişlik Düzeylerinin İncelenmesi”. Selçuk Üniversitesi Sosyal Bilimler Enstitüsü Dergisi 14 (2005) 115-129.

Aybay Y. (2006). “Kuzey Kıbrıs Türk Cumhuriyeti’nde Kadın Gazetecilerin Konumu”. Küresel İletişim Dergisi I (2006) 1-24.

Barut Y. \& Kalkan M. (2002). "Ondokuz Mayıs Üniversitesi Öğretim Elemanlarının Tükenmişlik Düzeylerinin İncelenmesi”. Ondokuz Mayıs Üniversitesi Eğitim Fakültesi Dergisi 44 (2002) 66-77.

Center for Disease Control. (2006). “Have a Stressful Job? You Must Have an Ulcer...Right?”. Available at: http://www.cdc.gov/ulcer/myth.htm

Çelik M. (2016). “Tükenmişilik Yaşam Doyumu ve İş Yükü İlişkisi: Denizli’de Faaliyet Gösteren Muhasebe Meslek Mensupları Üzerine Bir Araştırma”. Süleymen Demirel Üniversitesi Iktisadi ve Ídari Bilimler Fakültesi Dergisi 21/4 (2016) 1139-1152.

Delano A. (2003). "Women Journalists: What's the Difference”. Journalism Studies 4/2 (2003) 273-286.

Diener E., Emmons A. R., Larsen J. R. \& Sharon G. (1985). "The Satisfaction with Life Scale”. Journal of Personality Assesment 49/1 (1985) 71-75.

Doğan A., Demir R. \& Türkmen E. (2016). "Rol Belirsizliğinin, Rol Çatışmasının ve Sosyal Desteğin Tükenmişiliğe Etkisi: Devlet ve Vakıf Üniversitelerinde Çalışan Akademik Personelin Tükenmişlik Düzeylerinin Karşılaştırılması". Atatürk Üniversitesi İktisadi ve İdari Bilimler Dergisi 30/1 (2016) 37-67.

DPÖ (2015). http://www.devplan.org/Isgucu/2015.pdf

Ergin C. (1995). “Akademisyenlerde Tükenmişlik ve Çeşitli Stres Kaynaklarının İncelenmesi”. Hacettepe Üniversitesi Edebiyat Fakültesi Dergisi 12/1-2 (1995) 37-50

Freudenberger N. J. (1974). "Staff Burnout”. Journal of SocialIssues 30 (1974) 159-165.

George D. \& Mallery M. (2010). SPSS for Windows Step by Step: A Simple Guide and Reference. Boston 2010.

Gürel E. B. \& Gürel E. (2015). "Muhasebe Meslek Mensuplarının Mesleki Tükenmişlik Düzeyinin Yaşam Doyumu Üzerine Etkisi”. Muhasebe ve Denetime Bakış 44 (2015) 37-47.

Heppner P. P., Wampold B. E. \& Kivlighan D. M. (2013). Psikolojik Danışmada Araştırma Yöntemleri. Ankara 2013.

İrvan S. (2006). "Kıbrıslı Türk Gazetecilerin Etik ve Mesleki Değerleri”. Küresel Illetişim Dergisi 1 
(2006) 1-14.

Jung J. \& Kim Y. (2012). “Causes of Newspaper Firm Employee Burnout in Koreaandits Impact on Organizational Commitment and Turnover Intention”. The International Journal of Human Resource Management (2012) 1-16.

Karaman D. (2006). Türk Basınında Kadın Gazetecilerin Yönetim Kademelerinde Temsili. Yayımlanmamış Yüksek Lisans Tezi. İstanbul Üniversitesi Sosyal Bilimler Enstitüsü, İstanbul 2006.

KAYAD (2010). “Kıbrıs'ın Kuzey Kesiminde Kadınların Profili”. Kaynak: http://kayadcommunitycenter. com/KadinProfili.pdf

Kılıç A. (2013). Türk Basınında Kadın Gazetecilerin Yönetim ve Üretim Kademelerindeki Konumu. Yayımlanmamış Yüksek Lisans Tezi. Marmara Üniversitesi Sosyal Bilimler Enstitüsü, İstanbul 2013.

Köker S. (1991). Normal ve Sorunlu Ergenlerin Yaşam Doyumu Düzeylerinin Karşılaştırllmasıl. Yayımlanmamış Yüksek Lisans Tezi. Ankara Üniversitesi Sosyal Bilimler Üniversitesi, Ankara 1991.

Maslach C. \& Jackson S. E. (1981). “The Measurement of Experienced Burnout”. Journal of Occupational Behavior 2 (1981) 99-113.

Maslach C. \& Goldberg J. (1998). "Prevention of Burnout: New Perspectives”. Appliedand Preventive Psychology 7 (1998) 63-74.

Pavot W., Diener E., Colvin C. R. (1991). "Further Validation of the Satisfaction with Life Scale: Evidence Forthe Cross-Method Convergence of Well-Being Measures”. J. Personality Assessment 57/1 (1991) 149-161.

Polatçı S., Ardıç K. \& Türkan G. (2014). "Bağlılık Boyutlarının Tükenmişlik Boyutları Üzerindeki Etkisinin İncelenmesi”. Yönetim ve Ekonomi 21/2 (2014) 281-292.

Reinardy S. (2009). "Female Journalists More Likely to Leave Newspapers". Newspaper Research Journal 30/3 (2009) 42-57.

Şahin, F.S. (2013). “Kuzey Kıbrıs’ta Sarı Basın Kartı Sahibi Gazetecilerin Mesleki Tükenmişlik Düzeyi”. 8. Uluslararası Kıbrıs Araştırmaları Kongresi Bildiri Kitabı (2013) 197-212.

Tabachnick, B.G. \& Fidell, L.S. (2013). Using Multivariate Statistics. Pearson 2013.

Tekbıyık A. (2015). “İlişkisel Araştırma Yöntemi”. Kuramdan Uygulamaya Eğitimde Bilimsel Araştırma Yöntemleri (2015) 99-114. Ankara.

Uslan Ü. Y. (2016). "Kamu Çalışanlarının İş Doyumu, Yaşam Doyumu ve Tükenmişilik Düzeylerinin Bazı Sosyo-demografik Unsurlara Göre Değerlendirilmesi”. Journal of Human Sciences 13/2 (2016) 3354-3372. Doi:10.14687/jhs.v13i2.3983.

Ünal S., Karlıdağ R. \& Yoloğlu S. (2001). "Hekimlerde Tükenmişlik ve İş Doyumu Düzeylerinin Yaşam Doyumu Düzeyleri ile İlişkisi”. Klinik Psikiyatri Dergisi 4 (2001) 113-118.

Yıldırım G. (2016). "Okul Öncesi Öğretmenlerinin Meslekten Tükenmişlik ve Psikolojik Yılmazlık Düzeyi İlişkisi”. Electronic Turkish Studies 11/14 811-826. Doi: http://dx.doi.org/10.7827/Turkish Studies.9722.

Yılmaz A. \& Ekici S. (2003). "Örgütsel Yaşamda Stresin Kamu Çalışanlarının Performansına Etkileri Üzerine Bir Araştırma”. Celal Bayar Üniversitesi İ̈BF Yönetim ve Ekonomi Dergisi 10/2 (2003) 1-19.

Yumak G. G. \& Demiralay T. (2016). "Serbest Muhasebeci ve Mali Müşavirlerin İş Stresi Tükenmişlik Sendromu ve İş-Aile Yaşam Dengesi Arasındaki İlişkinin İncelenmesi”. Elektronik Sosyal Bilimler Dergisi 15/58 (2016) 917-938. Doi:10.17755/esosder.87776. 